\title{
ENGLISH TEACHER IDENTITY CONSTRUCTION: INDONESIAN TEACHERS' MOTIVATION AND STRATEGIES IN TEACHING ENGLISH FOR SPECIAL NEEDS STUDENTS
}

\author{
Yunika Upa ${ }^{1}$, Concilianus Laos Mbato ${ }^{2}$ \\ ${ }^{1}$ Sanata Dharma University, Yogyakarta \\ ${ }^{2}$ Sanata Dharma University, Yogyakarta \\ ${ }^{1}$ yunikayuni735@gmail.com, ${ }^{2}$ cons@usd.ac.id
}

\begin{abstract}
Being a teacher in special needs school is not an easy job. Besides having to possess knowledge about children with special needs, special needs school teachers are required to have high patience and good mentality at work. One factor that affects the teachers' success in educating students at special needs school is the teachers' motivation in carrying out their obligation. This study aimed to investigate what factors affected Indonesian teachers' motivation in shaping and developing their identities and what strategies they used in teaching students with special needs.Using a qualitative method, the researchers gained data by interviewing teachers from two special needs schools in Yogyakarta, Indonesia. After analyzing the data, the researchers found that both intrinsic factors such as the desire to assist students with special needs to be more independent, and extrinsic factors such as family, students, and colleaguesinfluenced the teachers' motivation to teach in special needs schools in Yogyakarta. These factors played an important role in developing and shaping the teachers' identity. The researchers also found that audio visual materials became the most effective and helpful strategies in teaching English for special needs schools. This study offers some suggestions for future researchers and Indonesian government.
\end{abstract}

Keywords: Teacher Identity, Motivation, Teaching Strategies, Audio Visual Materials

\section{INTRODUCTION}

Special needs education is education for special needs students who have a level of difficulty in following the learning process but have a potential of intelligence and special talent. Kryszewska, (2017) stated that special needs education are intended for students who have communication disorders, visual impairments, hearing impairment, autism, emotional behavior disorders and physical learning disabilities and development. Education provided to children with special needs, especially in formal schools, has an important role in optimizing the abilities that children have in special needs, namely through special education. The ability to take care of themselves, manage their behavior, communicate well and support other abilities in social life is an important goal of education for children with special needs.

The existence of special needs schools to educate students with special needs cannot be separated from the role of a teacher who conducts the process of teaching and learning activities. In the teaching and learning process that takes place, the teacher factor dominates the entire structure of educational factors. The teacher is essentially an important factor that must exist because the teacher has a big influence on his students. The teacher is not only a material giver, but also a counselor. But being a teacher is a huge challenge, especially being a teacher for children who have special needs. According to Kokkinos \& Davazoglou (2005), general 
education teachers have lower stress level than those in special needs schools. Special needs school teachers do not have an easy job but need more struggle and effort. Besides having to have knowledge about children with special needs and strategies to teach them, special needs school teachers are required to have high patience and good mentality at work.

One factor affecting the teachers' success in educating students at special needs schools is the teachers' motivation in carrying out their obligation. Teachers' motivation is a psychological process that encourages teachers so that they will enjoy the teaching process and make their goals fulfilled in the teaching process (Salifu \& Agbenyega, 2016, p.70). According to Richardson \& Watt, (2018, p.37), motivation is one of the important components in shaping and developing teacher's professional identity. Identity is related to how someone defines himself to himself and to others (Lasky, 2005, p. 901). According to Schutz et al, (2018), individual reflection and social communication with others are crucial to develop the teacher's professional identity, which in turn becomes a tool used by teachers to negotiate and reflect on the social aspects of their roles. Some motivational researchers said that identity can be divided into two types, namely ascribed and achieved identity (Schutz et al, 2018). Ascribed identity is the position or status of a person in society obtained from birth which are gender, race, caste, class, and line age while achieved identity appear from individuals' personal agency, option, venture, and tenacity. Both types of identity play a role in shaping and developing teacher identity because they choose to be a teacher to teach as a career entangling "individual qualities, expectancies, values, beliefs and talents, as well as accommodating required social roles, responsibilities, and expectations".

According to Richardson \& Watt, (2018), motivation is one of the important components in shaping and developing teacher's professional identity. Teachers' motivation is related to how they view themselves and the work they do. Teachers' motivation also has a close relationship with a number of variables in education such as education reform, student motivation, teacher teaching practices, teacher welfare, and psychology of the teachers (Han \& Yin, 2016). Teachers' motivation is a psychological process that encourages teachers so that they will enjoy their teaching process and make their goals fulfilled in the teaching process (Salifu \& Agbenyega, 2016). Motivation is formed by the attitude of a teacher in dealing with work situations. Motivation is a condition that drives someone who is directed to achieve their goals in educational. Motivation is part of a person's performance to achieve or achieve their goals for certain factors. In accordance with its nature, human needs are diverse, both types and levels, even humans have needs that tend to be infinite. It means that the needs always increase from time to time and humans always try with all their abilities to satisfy those needs. Human needs are interpreted as everything they want to have, achieved and enjoyed. So, the researcher concludes that motivation is an effort that is based on directing and maintaining one's behavior so that he is motivated to act to do something to achieve certain results or goals.

There are two factors affecting motivation. They are intrinsic and extrinsic (Salifu \& Agbenyega, 2016). Similarly, Jang, (2019) and Gultekin \& Erkan, (2014) state that, motivation could come from within the teacher himself (intrinsic) and be influenced by factors outside of the teacher (extrinsic). Intrinsic factors are an impulse from someone, and there is no need for external stimulation to achieve their goal (Gultekin \& Erkan, 2014). Thus, teachers' intrinsic motivation can also be said as a form of motivation in which teaching or learning activities begin and are continued based on an inner motivation and are absolutely related to their teaching or learning activities. On the other hand, extrinsic motivation is motivation that comes from outside someone, which also determines one's behavior in achieving their goals (Gultekin \& Erkan, 2014). Thus, teachers' extrinsic motivation refers to something that comes from outside and is separate from the teacher's behavior. The teacher's work environment can influence the 
teacher's motivation, such as students' characteristics, the mandated curriculum (Tehseen\&Hadi, 2015), relationship with colleagues, and interactions with parents. These factors affect, shape and change them as teachers.

One of the main factors that influence teachers' motivation is student behavior (Tehseen\&Hadi, 2015). Many studies have found that teachers and students have a close relationship in the teaching and learning process. According to Liu and Meyer as citied by Tehseen\&Hadi, (2015) the level of teachers' dissatisfaction in teaching is influenced by students' behavior and classroom management. Students' characters such as lack of discipline and students' motivation are the main factors that can influence teachers' motivation (Haberman\& Richards as citied by Tehseen\&Hadi, 2015). The second factor is the curriculum mandated. According to Ingersoll and Smith as citied by Tehseen\&Hadi, 2015) the curriculum mandated has an influence on the teachers' motivation. Many responsibilities imposed on teachers such as the preparation of lesson plans and other learning tools can affect the motivation of teachers in the learning process of students. The third factor influencing the teachers' motivation is, colleagues working in the school. Thus, numerous studies said that a positive relationship among teacher and their colleagues influence their ambition to stay at school (Tehseen\&Hadi, 2015)

Based on the explanation above, the researchers concluded that motivation is an important factor for teachers to achieve their goals in the learning process. Given that teachers are likely to face social problems, this study investigated motivation variables that were expected to represent the factors influencing the teachers' motivation in teaching students in Special Needs Schools in Yogyakarta, Indonesia. These factors could arise from within the teachers themselves (intrinsic) and from outside the teachers (extrinsic). The researchers assumed that these two kinds of motivation had a big influence in the teachers' identity development as teachers at state and private special needs schools in Yogyakarta, Indonesia.

Teaching strategies are a series of and overall teacher's strategic actions in realizing the realization of effective and efficient actual learning activities, for achieving learning goals. The selection of teaching strategies greatly influences the success of student learning. This statement supported by Dumford et al, (2016) who argued thatteaching strategies has an important role in the success of classroom learning goals. Thus, it is important for the teachers to choose the right learning media to support the success of student in learning EFL. Apsari et al, (2020) stated that "the use of learning media is one of the efforts for the creation of meaningful and enjoyable English learning for young children".

One of the learning media used is audio visual media. Audio visual media are a set of tools used to display animation and audio so that they can form the same character as the original object because of the integration between the image and sound displayed (Burton as citied by Muliana, 2018). Numerous studies have investigated the use of audio visual media in teaching. According to $\mathrm{Al}$, (2014) teaching students by using audio visual media can motivate them in the learning process. Using audio visual materials as a teaching strategy will make the classroom more interactive and lively because it brings the real world in the classroom. Furthermore, Muliana, (2018) audio visual media are very effective for the teachers to teach pronunciation for the students is since they can improve students' pronunciation.Thus, the researchers concluded that the use of audio visual media in learning can help educators deliver learning materials so that students could improve their learning and achievement.

Based on the description above teachers' motivation has an influence on their performance. Numerous studies have shown about the important of teacher motivation in developing teacher 
identity. However none of the research has shown the factors affecting Indonesian teachers' motivation to shape and develop their identity at special needs schoolsand strategies to teach English to students at special need schools. This study aimed to investigate what factors affecting Indonesian teachers' motivation in shaping and developing their identities and what strategies they used in teaching students with special needs. To meet the objectives, the following research questions were formulated:

1. What are the factors affecting Indonesian teachers' motivation to shape and develop their identity at Special Needs Schools?

2. What are the strategies to teach English to students at Special Need Schools?

\section{METHOD}

The intention of this study was to investigate the teacher identity, motivation, and teaching strategies in special needs schools in Yogyakarta, Indonesia. The researcher gained data by using qualitative descriptive that allowed the researcher to collect rich data of teachers' thoughts, perspectives, feelings, and social environment (Seidman, 2006; Creswell 2014)

The researcher collected the data at Special Needs Schools in Yogyakarta, Indonesia. There were two teachers who voluntarily became the participants in this study. The first participant was a female teacher who had eight years of the teaching experience at a State Special Needs School, also in Yogyakarta, Indonesia. Before teaching at State Special Needs School, she taught at a Vocational High School as an English teacher for 4 years. The second participant was a female teacher who had eleven years of teaching experience at a Private Special Needs School in Yogyakarta. They were interviewed to know the factors affecting their motivation in shaping and developing their identity at special needs school and the strategies undertaken to teach English for students in that special needs school.

In this study, the researchers gained data from two sources that is interviews and field observation. The interviews were semi-structured and recorded. The researcher asked the participants' feelings when they taught at the first time at Special Needs School. Then the researcher also focused on the participants' teaching experience, including their daily work and teaching practice, interaction with the students and colleagues, administration (the mandatecurriculum), parents' demand and their feelings as Special Needs' teachers. The researchers also asked about the factors affecting their motivation in shaping and developing their professional identity and their strategies in teaching English for students with special needs. The researchers did the interview for two times. Filed observation was also an important source in this study, which includes the interaction of participants among students with special needs and the participants' teaching. The researchers took notes of the important things during the observation such as the interaction between the teachers and the students with special needs.

After collecting the data, the researchers transcribed the interview. The researcher used opened coding to analyze the interview data. After that, the transcript of the interview was segmented into meaningful units with a series of identify themes and categories, mainly related to the identity of participants, as well as possible reasons for forming theiridentities. After that, the emerging categories were re-examined and rearranged to form meaningful relationships with reference to the conceptual framework adopted in this study, such as the emotional process of forming teacher identity. While for the field observations, the researchers identified the important events during the observation regarding to the teachers' motivation in developing their identity. 


\section{RESULTS AND DISCUSSION}

\section{Results}

The results of data analysis attempted to describethe teachers' motivation in developing their professional identity and their teaching strategies at private special needs schools in Yogyakarta. The research questions of this study were: What are the factors affecting Indonesianteachers' motivation to shape and develop their identity at a Special Needs School in Yogyakarta and what are the strategies to teach English to students at a Special Need School in Yogyakarta?

Thefollowingpresents theresults oftheinterview and field observation involving two teachers of two Special needs school in Yogyakarta. The researcher labeled the teacher transferred from a state special needs school as Teacher A and the teacher from a private special needs school as Teacher B).

\section{The factors affecting teachers' motivation in shaping identity}

The data shows that every participant has own reasons to be a teacher. The reason why they chose to be a teacher was the inspiration from their previous teachers and parents.

I was inspired by my elementary teacher. She was a social sciences subject teacher. She has different teaching methods from other teachers. She teaches students with different methods. The teacher taught us by using songs and games so we never felt bored with him. She made us comfortable when studying. She was never angry with us when we made a mistake but she would approach us by making her students felt comfortable. She would find out the cause of our mistake by asking the reason gently without any anger. For me, she was not only a teacher but as a counseling guidance teacher for her students. (Teacher A)

Teacher B chose to be a teacher because her parents asked her to be a teacher as shown in the following quote:

My parents worked as teachers so I also follow in his footsteps because they wanted me to be a teacher. I was inspired by my father to become a teacher because he was a simple teacher who taught with all limitations. He used makeshift media to teach so that the learning process continued. (Teacher B)

The interview above showed that family andprevious teachers are the factors for the participants to choose teaching as their career. They became inspiration for them to be a teacher. Participant $\mathrm{B}$ felt comfortable in the learning process because the teacher always teaches the students by using games and song. The teacher also played a role as a counselor to the students when the students experience problems, especially in the learning process. On the other hand, the other participant chose teaching as her career because the participant's parents always encouraged her to be a teacher. The participant also admired her father because he always taught his students with enthusiasm despite all the limitations

As we know that teaching in special needs school need patient because the teachers work with special needs students. The data below shows the participants' feeling and opinion in teaching 
special needs students. They believe that teaching special needs students were mandated from God and a calling from their heart.

"I knew this Special Needs School from my friend. But over time, I feel comfortable. I feel that I was called to teach students with special needs this place. I feel that I had a heart with students here because the students here are different from the others. Teaching in this place is a call from my heart. If not from my heart, maybe I have left this job from a year ago and I feel that teaching in this place is my calling from God for students with special needs in this place. Even though it is as difficult to face the characters of this student, but I will be able to be patient because of my love for my students. (Teacher $A$ )

For me, teaching students with special needs is my faith in worship. I consider my students with special needs as the Mandate of the Almighty. (Teacher B)

The data above showed that the participants felt comfortable teaching in special needs school because of their love for the students and it was mandated from God as well as a faith in God

Every teacher has their own goals in teaching their students especially for the teachers who teach in special needs school. One of their goals in teaching students with a special needs school is helping them to be independent. Helping them to be an independent is a pride for the teachers.

I want to make my students to be independent, at least button their clothes or wear their own clothes, it is a matter of pride. Although it is a little things but I am proud when making at least an increase for my students in taking care of themselves. Because when students didn't show their development, it is a burden for me as their teacher. At least using their shoes by themselves will make me proud because the needs of students in special needs school are different, so they need special guidance. (Teacher A)

I have a great desire to make my students independent and skilled because it is a pride for me. (Teacher B).

The data above showed that both teachers had a similar goal in teaching students with special needs. Their goal was to assist their students to be independent. This goal gave them a sense of pride particularly when they could help their students to be independent.

Both participants also said that they had obstacles inside the classroom and outside the classroom to achieve their goals in teaching the school. The obstacles were students' mood, theteachers' retirement, and society.

If the students felt unwell, the students would become ineffective in learning process. Sometimes the emotions of the students who are unstable cause causing students to become fussy. Besides that, the atmosphere is not conducive when one student cries and the other cries. Every year the teachers' class will be changed, teachers must need adaptation by recognizing the character of the students first. The teacher also must know what the students like. The teacher must know the needs of children, and adjust children's abilities. (Teacher A) 
The current obstacle is the teacher's limitation, because this year, there are many high school teachers who retire. Students in class have different limitations and we need a lot of energy to guide them because they need special attention. For obstacles outside the classroom, I want to make children feel accepted in the community and not feel discrimination anymore.

Administration is tiring. Making administration won't be enough. Teachers here to teach why are being illiterated with bureaucracy and administrative demands. Administration spends time. When teacher are busy with the administration and bureaucracy, the students will be ignored. Administration is very burdensome. (Teacher B)

The data above showed that students' condition were decided by the students' condition such as their readiness in the learning process. If the students felt unwell or their emotional were not stable, they would becomefinicky. The other obstacle was the teachers' limitation. They complained about the great number of teachers retiring, which would certainly reduce the number of teachers in the special needs schools. This would not help much since special needs schools still needed more teachers to helpstudents with a special guidance because every student had a different need. The participants also said that they wanted to help their students to beaccepted in their environment or society.

In addition the teachers stated that administration was tiring for the teacher. When the teachers were busy with the administration, the students would be ignored and this administration work was only a waste of time for them. The other obstacle was that the teachers had to adapt with students' characteristic when the new teachers were appointed.

Being a teacher is a huge challenge, especially for children who have special needs. Teacher in a special needs school needs more struggle and efforts. Besides having to have knowledge about children with special needs and strategies to teach them, special needs school teachers are required to have patience and good mentality at work. The participants mentioned students, colleague, administration, and family the factors influencing their motivation to survive as a teacher in special needs school.

Colleagues have an influence on me. If colleagues do not help each other, so maybe my performance would not survive until now and would not survive until for 11 years. But because of working together, and my colleagues are solid team that supports each other so that I can survive until now. The most influential is the development of my students and I want to make my students accepted in society and also support from my family (Teacher A)

What kept me going until now was the encouragement from the family and the development of students that made me even more motivated. On the other hand I want to make my students accepted in society. Because nowadays, students with special needs in the community are often ridiculed and discriminated against and still not accepted. The teacher is sometimes discriminated against. I have participated in the national Olympics by making research proposals. After the proposal in the ACC and conducting research, my name was dropped because I 
was from special needs school. Since then I became more determined to make my students accepted in society. (Teacher B)

The data above showed that the colleagues motivated the participants' to be a teacher there by giving support, solidity, and the commitment to always working together. Both participants said that family and students were also a reason to keep them survive as a teacher in a special needs school. In addition, the participants wanted to make their students accepted inthe society and did not get discriminated by society.

\section{The teachers strategies in teaching English for special needs students}

Learning media greatly influences the success of the learning process. EFL learning for students with special needs requires the right strategies, varied techniques, and preparation of material that takes into account the needs of students so that the learning objectives that have been set can be achieved. Meanwhile, the selection of EFL material for students with special needs, are basic material such as the introduction of vocabularies about the names of animals, fruits, and things in the classroom. Therefore the selection of teaching strategies greatly influences the learning success of students, especially students with special needs. In this study the researchers found that the use of audio visual media in teaching special needs students was really helpful for the teachers to achieve their teaching goals.

So far, the EFL lessons that I have taught for my students are the names of vocabulary objects, things in the classroom. To deliver this material I always use audio visual like playing a recording in every meeting. This strategy really helped me in teaching my students with special needs. (Teacher A)

Actually, I got several assignments to teach English for several years but because the class was now mixed with other classes so I taught him sometimes in the hall using a large TV to teach my students. Teaching English is most effective when using a large TV. For teaching vocabulary, I use video because I think using videos is safer and more effective because the students with special needs here are still very difficult to write and read. So for the material I downloaded it on youTube and played it on a big TV. Through the video I released, they will dance, sing and play while learning. (Teacher B)

The data above showed that teaching strategies by using audio visual was helpful and effective in teaching students with special needs. In addition, the teachers also stated thataudio visual media were safer to use in teaching students with special needs than other media. These media also encourage students to dance, sing and ply while learning students dance, sing, and play while learning.

\section{Discussion}

The results of the study above indicated that motivation has an important role for the teachers in special needs schools. Teacher's motivation is related to how they view themselves and the work they do. The teacher motivation in special needs school are influenced by both intrinsic and extrinsic factors. The teachers in special needs school has high motivation because the 
teachers are supported by their family, students' development, colleague, and administration. This finding supports Tehseen \& Hadi's(2015) theory that the teachers' work environment can influence teachers' motivation, such as students' characteristics, the mandated curriculum, relationship with colleagues, and interactions with parents.

Intrinsically, the teachers' motivation was influenced by themselves, to make the students with special needs become independent. According to Gultekin \& Erkan, (2014) intrinsic factors is an impulse from someone, and there is no need for external stimulation to achieve their goal. Thus, the teachers' intrinsic motivation can also be said as a form of motivation in which teaching or learning activities begin and are continued based on an inner motivation and are absolutely related to their teaching or learning activities. On the other hand, based on extrinsic factors, the teachers were influenced by the family, students, colleague, and the administration. These factorsaffect, shape, and change who they are as a teacher (Schutz et al, 2018).

After analyzing the factors, it was found both intrinsic factors and extrinsic factors influenced the teachers' motivation. It is clear that both intrinsic and extrinsic factors of the teachers' motivation have an important role in shaping and developing their identity as a teacher in special needs school and in achieving their goals in the teaching learning process.By having strong intrinsic and extrinsic motivation, teachers are expected to be dedicated in teaching, and always pay attention to the students' learning needs, so that the students' could enjoy learning and achieve better.

In addition, it was revealed that the two participants chose to be a teacher because their parents were educators, and they were inspired by their family and their previous teachers. According to Schutz et al, (2018) there are two types of teacher identity, ascribed achieved. Ascribed identity is the position or status of a person in society obtained from birth with gender, race, caste, class, and line age while achieved identity appears from individuals' personal agency, option, venture, and tenacity. Both types of identity played a role in shaping and developing the teachers' identity because they chose to be a teacher to teach as a career entangling individual qualities, expectancies, values, beliefs and talents, as well as accommodating required social roles, responsibilities, and expectations. Teacher a demonstrated achieved identity. She chose to be a teacher because she was inspired by her teacher. She started teaching at a special needs school when her friend gave her information about teaching vacancy in private special needs school and since then she had felt so comfortable in teaching the students. On the other hand, the other participant could categorize having ascribed identity. The participant chose to be a teacher because her parents were educators so her parents asked her to be a teacher. She also admired her father and made her father as her inspiration.

The teachers admitted that audio visual media were effective in teaching EFL for students with special needs. According to Al, (2014) teaching students by using audio visual can motivate students in the learning process. Using audio visual media as a teaching strategy will make the classroom more interactive and lively because it brings the real world in the classroom.

\section{CONCLUSION}

Based on the findings, the researchers concluded that both extrinsic and intrinsic factors influencing the teachers' motivation in special needs schools in Yogyakarta. The intrinsic motivation is the motivation that comes from themselves to help the students to become independent and be accepted in the society. In addition the extrinsic motivation is influenced by their family's support, students' development to be independent, and their colleague's. The teachers also said that administrative work also reduced their motivation to be a teacher. The 
teachers' extrinsic factor limiting the teachers' motivation to be a teacher was imminent teachers' retirement. In addition, using audio visual in teaching English is found to be effective and helpful for students with special needs. Despite the encouraging results, this research has a limitation. It has a very small sample $(\mathrm{N}=2)$. The researchers suggest future researchers to conduct further research on the teachers' motivation in teaching special needs students with a bigger sample and relate it to other variables not found in this study. For the government it is important to pay attention to special needs schools particularly in terms of the number of teachers, the learning facilities and the teaching learning process.

\section{ACKNOWLEDGMENTS}

Place Acknowledgments, including information on the source of any financial support received for the work being published. Place Acknowledgments, including information on the source of any financial support received for the work being published.

\section{REFERENCES}

Al Mamun, M. (2014). Effectiveness of audio-visual aids in language teaching in tertiary level (Doctoral dissertation, BRAC University).

Apsari, Y., Lisdawati, I., \&Mulyani, E. R. (2020). Alatpermainanedukatifsebagai media pembelajaranbahasainggris. AbdimasSiliwangi, 3(1), 38-47.

Creswell, J. W. (2015). 30 essential skills for the qualitative researcher. Sage Publications.

Dumford, A. D., Cogswell, C. A., \& Miller, A. L. (2016). The who, what, and where of learning strategies. The Journal of Effective Teaching, 16(1), 72.

Gultekin, H., \&Erkan, A. C. A. R. (2014). The intrinsic and extrinsic factors for teacher motivation. Revista de cercetaresiinterventiesociala, 47, 291.

Han, J., \& Yin, H. (2016).Teacher motivation: Definition, research development and implications for teachers. Cogent Education, 3(1), 1217819.

Jang, H. R. (2019). Teachers' intrinsic vs. extrinsic instructional goals predict their classroom motivating styles. Learning and Instruction, 60, 286-300.

Kokkinos, C. M., Panayiotou, G., \& Davazoglou, A. M. (2005).Correlates of teacher appraisals of student behaviors. Psychology in the Schools, 42(1), 79-89.

Kryszewska, H. (2017). Teaching students with special needs in inclusive classrooms special educational needs.

Lasky, S. (2005). A sociocultural approach to understanding teacher identity, agency and professional vulnerability in a context of secondary school reform. Teaching and Teacher Education, 21, 899-916.

Muliana, S. R. (2018). The Role of Audio Visual to Develop Students' Pronunciation (A Study at English Department of UIN Ar-Raniry) (Doctoral dissertation, UIN Ar-Raniry Banda Aceh).

Richardson, P. W., \& Watt, H. M. (2018). Teacher professional identity and career motivation: A lifespan perspective. In Research on teacher identity (pp. 37-48).Springer, Cham.

Salifu, I., \&Agbenyega, J. S. (2016). Teacher motivation and identity formation: Issues affecting professional practice. MIER Journal of Educational Studies, Trends and Practices, 3(1).

Schutz, Paul A., \& Hong, J. (2018).Research on Teacher Identity: Mapping Challenges and Innovations. New York: Springer 
Seidman, I. (2006). Interviewing as qualitative research: A guide for researchers in education and the social sciences. Teachers college press.

Tehseen, S., \&Hadi, N. U. (2015). Factors influencing teachers' performance and retention. Mediterranean Journal of Social Sciences, 6(1), 233. 